\title{
Role of $\mathrm{HR}$ in Designing \& Implementing the Competency Models
}

\author{
Neeraj Kumari* \\ Faculty of Engineering \& Technology, Manav Rachna International University, Faridabad, India \\ *Corresponding author: neerajnarwat@gmail.com
}

Received August 29, 2014; Revised October 10, 2014; Accepted October 20, 2014

\begin{abstract}
The aim of the paper is to study the concept of competency mapping in the organization and how does Human Resource department of the organization focuses to provide a definitive road map to understand, design and implement competency models in an organization. Descriptive research design has been followed in the study. The data was collected from 75 employees working at DMRC, barakhamba road with the help of a structured questionnaire. The analysis of the questionnaire has been done through SPSS. It was found that the company has cost effective system to recruit and select people which is working satisfactorily. DMRC frequently employ some form of competency mapping to understand how to most effectively employ the competencies of strengths of workers.
\end{abstract}

Keywords: assessment, development, human resource, job position, planning

Cite This Article: Neeraj Kumari, "Role of HR in Designing \& Implementing the Competency Models." Journal of Business and Management Sciences, vol. 2, no. 4 (2014): 83-89. doi: 10.12691/jbms-2-4-1.

\section{Introduction}

Human resource management is a process of bringing people and organizations together so that the goals of each other are met. Nowadays it is not possible to show a good financial or operating report unless your personnel relations are in order. Over the years, highly skilled and knowledge based jobs are increasing while low skilled jobs are decreasing. This calls for future skill mapping through proper HRM initiatives. Indian organizations are also witnessing a change in systems, man-agreement cultures and philosophy due to the global alignment of Indian organizations. There is a need for multi skill development. Role of HRM becomes more important.

Competency Mapping is a process of identifying key competencies for a company or an organization and the jobs and functions within it. Competency mapping is important and is an important activity. Every well managed organization should have well defined roles and list of competencies required to perform each role effectively. Competency mapping analysis individual's SWOT for better understanding and this helps to improve his career growth. This identifies the gap for improving knowledge to develop. Every industry in the present scenario is trying to achieve high efficiency and effectiveness in order to survive in this cutthroat competition. Industry is basically classified into production and service sector. They try desperately to improve the efficiency of their system. All the methods and approaches for improving the performance and efficiency of their operations points to a basis key factor "Skill and Competency. Skills and competency, therefore, becomes a focal point of companies, which aims at improving their performance. Every industry, especially production industries, emphasizes on skill and competency. It becomes mandatory for any production company, aiming at improving their performance, to map the skill level of their workers.

Skills mapping is a technique of studying and analyzing the skills possessed by the persons concerned. It is a comprehensive way of knowing the skill levels of the persons. Skill mapping evolves a result, which not only specifies the skill level of the persons but also identifies the Gray areas where improvement can be made by training or by other means. Skill mapping, thus, is fast becoming important, buzzword for any industry aiming at revamping them-selves to the present competitive situation. It is becoming popular day by day and many companies are showing keen interest in using this technique to improve their efficiency. Companies are vastly shifting their approach of having multi-skilled employees with knowledge of only one skill. Companies are interested in knowing the present skill level of their employees so that training can be given to improve their performance. This is where skill Mapping comes in to focus, which apart from mapping the skills also helps in identifying the strategies for multi skilling program for the company. With increased importance to operational efficiency, cost-reduction, higher productivity norms and managing with fewer employees than before by corporate, brings competency as the most important yardstick for all Human Resource - related decisions like selection, assimilation, development, growth charting and promotion, etc. The competence approach focuses on linking business strategies to individual performance efforts. It also encourages employees to develop competencies which can 
be used in diverse work situations rather than being boxed into the job. Development of employees focuses on enhancing their competencies rather than pre-paring them for moving to jobs. In this way they can develop capabilities useful throughout the organization as it changes and evolves.

Human resource management is a process of bringing people and organizations together so that the goals of each other are met. Nowadays it is not possible to show a good financial or operating report unless your personnel relations are in order. Over the years, highly skilled and knowledge based jobs are increasing while low skilled jobs are decreasing. This calls for future skill mapping through proper HRM initiatives. Indian organizations are also witnessing a change in systems, management cultures and philosophy due to the global alignment of Indian organizations. There is a need for multi skill development. Competency Mapping is a process of identifying key competencies for an organization, the jobs and functions within it. Competency mapping is important and is an essential activity. Every well-managed firm should have well defined roles and list of competencies required to perform each role effectively. Competency mapping identifies an individual's strengths and weaknesses in order to help them better understand themselves and to show them where career development efforts need to be directed. Competency mapping is not only done for Confirmed employees of an organization and it can also be done for contract workers or for those seeking employment to emphasize the specific skills which would make them valuable to a potential employer. These kinds of skills can be determined, when one is ready to do the work. Competency mapping is one of the most accurate means in identifying the job and behavioral competencies of an individual in an organization.

\section{Types of Competencies}

1. Generic or specific Competencies: This means competence is thought of in terms of knowledge, abilities, skills and attitudes displayed in the context of a carefully chosen set of realistic occupational tasks that are of an appropriate level of generality.

2. Generic Job Responsibilities:

- Directs day-to-day operations for a limited activity.

- Allocates or uses resources affecting closely related activities. Gives or obtains information to get the job done and to meet deadlines.

3. Threshold or performance Competencies: Basic competencies required to do the job, which do not differentiate between high and low performers. Performance competencies are those that differentiate between high and low performers. The characteristics required by a jobholder to perform a job effectively are called threshold competencies.

4. Core Competencies: A core competency is defined as an internal capability that is critical to the success of Business. These are organizational competencies that all individuals are expected to possess. These competencies define what the organization values the most in people. They are flexible and evolve over time.

5. Differentiating competencies: The characteristics, which differentiate superior performers from average performers, come under this category; such characteristics are not found in average performers.

\section{Uses of Competency Mapping}

- Assessment during recruitment, through specific work-based exercises and relevant, validated, psychometric tests,

- Assessment during auxiliary development; as a profile during assessment to guide future development needs,

- Succession planning and promotion,

- Organizational development analysis.

- It serves as a means to ascertain that an organization's knowledge and capabilities are in alignment with its strategy.

- It makes use of sophisticated mapping between competency taxonomy and multiple content taxonomies. This kind of multiple mapping between taxonomies requires the use of information organizations known as ontology.

\section{Competency Mapping (3 Step Process)}

Step 1: Frame the Competence Map for a job role Step 2: Competency Assessment

Step 3: Competency Grading

\subsection{Corporate Advantage}

- Candidate Appraisal for recruitment

- Employee Potential Appraisal for promotion or functional shift

- Employee Training Need Identification

- Employee Performance Diagnostics

- Employee Self Development Initiatives

Step 1: Frame the Competence Map for a job role

- Understanding Job Positions

- Data Collection

- Role definition and job detailed job descriptions with Job Factors

- Competency Map

Step 2: Competency Assessment

- Tool used : Behavioral Interview/ Employee Survey Method

- Behavioral Interview: One to one interaction with employees. Descriptive and situational based questions.

- Survey Method: Detailed Questionnaire to be filled by employees with situational examples to support

Step 3: Competency Grading

- Grades are allotted to each employee at different levels, based on the competency map and the assessment.

- A percentage grid would be designed.

- Training needs would be identified for departments

\section{Literature Review}

According to Duke Levin (2008), to map the competencies required for any job position in the 
organization, the job position needs to be understood in the context of the business operation. Business organizations are an important part of civil society. These organizations exist to satisfy some social need. No organization can exist if it is not satisfying a social need. To satisfy a social need organization has to carry out different types of tasks. Organizations plan the activities and the responsibilities in such a way that similar type of activities requiring similar resources and expertise are entrusted to the same employees or same group of employees.

According to Leong, J. (2008), Competency mapping alone may not produce accurate results unless one is able to detach from the results in analyzing past successes and failures. It is about identifying ideal behaviors and personal skills which distinguish exceptional and stupendous performance from the average. This aids in setting standards of behavior and thereby performances for the average work force to follow.

According to Tammaro (2005), Competency maps provide employers with concrete and objective information usable in all employment decisions. As a matter of fact competency is a behavioral and demonstrative ability that is informed to some degree by a conceptual perception.

Travis et al. (2004), In a dynamic environment, health managers need to combine leadership, entrepreneurial and administrative skills to meet the challenges that the changing socio-political, economic and technological landscape presents, as well as the expectations of patients, health professionals, politicians and the public. Without good management we will not be unable to improve efficiency, effectiveness and responsiveness in the delivery of health services or upscale interventions to achieve health goals.

Calhoun \& et. al. (2004), Determining and assessing competencies is a vital precursor to improving professional development and the alignment of individual development with the need of an organization or profession. The competency-based approach to professional development is well accepted in higher education and in human resource management literature where it is regarded as a critical part of the overall management development process, as it allows one to identify the gaps between current skills and the skills required.

Gough and Price (2004), Appropriate programmes based on the personal needs and experiences of health managers can be put in place to train managers to provide leadership and to ensure a sustainable improvement in the work context of health workers, and hence on the quality of care and health of the communities their organizations serve.

Lehman \& et. al. (2002), Managers need to develop several competencies that will enable them to perform these functions effectively and efficiently. Managerial competencies are 'sets of knowledge, skills, behaviors and attitudes that a person needs to be effective in a wide range of managerial jobs and various types of organizations'. Of particular importance are strategic skills that relate to the setting of key objectives based on an understanding of what is happening inside and outside the organizations; task-related skills that encompass functional and operational competencies that enable managers to define the best approach to achieving objectives, given the resources available; people-related skills that enable managers to achieve objectives through and with others; and self-management skills that enable managers to take responsibility for their life at work and beyond.

According to UNIDO (2002), A Competency is a set of Skills, related knowledge and attributes that allow an individual to successfully perform a task or an activity within a specific function or a job.

Austin, Klimoski, and Hunt (1996) have recently designed a micro-level framework that uses stakeholder participation to develop and implement selection systems in the public sector. Their framework is based on the values of fairness, technical adequacy, and feasibility as viewed individually and collectively by political entities, management, labour unions, system designers, and human resource managers.

The American Compensation Association (1996) conducted a major survey of $217 \mathrm{mid}$ to large size organizations to determine their use and experience with competencies. The survey pointed to wide use of competencies, but to varying degrees of rigour and application. The survey found organizations using competencies for:

- Communicating valued behaviours and organizational culture (75\% agreed competencies have a positive effect)

- "Raising the bar" of performance for all employees (59\% agreed)

- Emphasizing people (rather than job) capabilities as a way to gain competitive advantage (42\% agreed)

- Encouraging cross-functional and team behaviour (34\% agreed)

Winter (1996) has described how Guardian Insurance uses competencies to assess and reward individual performance in terms of core competencies that reflect the company's strategic focus and priorities and how Bell Sygma applies the notion of competencies to all aspects of human resources management, starting with the HR plan. In the latter case, gap analysis provides the basis for behavioural-based interviews to select candidates who fit with their core competencies, for an individual development process, for succession planning, and for job definition determined by the competencies an employee applies.

Hendry and Maggio (1996) suggest that when competencies are linked to the broader goals of an organization, the following common elements emerge as outcomes of a comprehensive competency model:

- Identification of characteristics and behaviours that differentiate top performers from others in relation to their contribution to strategic objectives;

- Clarification, communication, assessment, and development of characteristics that focus individuals on core organization goals;

- Practical observation helps prescribe and validate behavioural descriptions that achieve the desired results;

- Description of skills, attitudes, traits, and behaviours that can be attached to pay, performance measurement, hiring criteria, training, organizational staffing, career development, and succession planning. 
Bryson (1995) describes several methods by which public sector and nonprofit organizations can identify their organizational core competencies as a significant output of the strategic planning process. For example, a strategic consideration of a public sector organization's strengths and weaknesses can identify its organizational core competencies in concrete terms. Improvement of organizational core competencies can then be achieved through coordinated adjustment of HRM administrative policies and practices covering all, or selected, personnel functions. In some cases even in public sector settings, it may be important to ensure that an organization's competency model be explicitly future oriented, rather than implicitly historic, and that it identifies levels of superior strategic performance rather than levels of threshold, or minimum, operational performance.

According to Hamel and Heene (1994), Battle lines are drawn concerning where competencies should come from and which ones should be used. Strong support exists for the development of competencies that provide unique advantage over competitors. This argument suggests that unless unique competencies provide a source of competitive advantage and add value to an organization's customer relationships, the firm will not have needed skill, behavior and knowledge advantages.

Fogg (1994) defines organization core competency as "those few internal competencies at which you are very, very good, better than your competition, and that you will build on and use to beat the competition and to achieve your strategic objectives."

Dubois (1993), defines competence as "the employee's capacity to meet (or exceed) a job's requirements by producing the job outputs at an expected level of quality within the constraints of the organization's internal and external environments." He goes on to adapt Boyatzis' (1982) definition of competency and states that "a job competency is an underlying characteristic of an employee--i.e., motive, trait, skill, aspects of one's selfimage, social role, or a body of knowledge-- which results in effective and/or superior performance in a job."

Dubois (1993), in defining competency models states that they "provide the adhesion or "glue" that is necessary among the elements of an organization's human resource management system. By this I mean that competency models help organizations take a unified and coordinated approach to designing the human resource management system, including job design, hiring, performance improvement, employee development, career planning, succession planning, performance appraisals, and the selection and compensation systems for a job. Therefore, any investment an organization makes in competency model development work has benefits beyond the usefulness of the results for HRD purposes."

Snow and Snell (1993) illustrate how staffing plays a key role in the realization and consolidation of major shifts in strategy and structure, ranging from a job-person match function, to a strategy implementation function, through to a strategy formation function. An effective competency-based staffing model in the public sector will require improved methods for designing and maintaining managerial assessment and selection tools appropriate to its function or transitional state. Consultative methods (e.g. joint consultation), effective documentation, and active strategic monitoring and maintenance is essential for the attainment and long-term viability of functionally appropriate competency-based staffing models in the public sector.

According to Schuster and Zingheim (1992), Values, processes and pay structures may vary from organization to organization and influence how pay gets the message across. However, strategic alignment is the goal. Pay systems designed to communicate strong messages of strategy and directions are necessary to generate organizational performance. On the other hand, pay systems that emphasize values such as bureaucracy, entitlement and internal equity may not be practical for organizations that must compete for business and talent.

According to Senge (1990), Companies hope to outlearn their competitors by making knowledge a tool of advantage. This is especially true for knowledge-based work that most believe will continue to account for much of needed productivity, quality and other value-added gains.

Furnham (1990), states that "the term competence is new and fashionable, but the concept is old. Psychologists interested in personality and individual differences, organizational behavior and psychometrics have long debated these questions of personality traits, intelligence and other abilities."

McClelland's (1973) competency methodology can be summed up in two factors: "Use of Criterion Samples" or systematically comparing superior performing persons with less successful persons to identify successful characteristics and "Identification of Operative Thoughts and Behaviours that are Causally Related to Successful Outcomes" or the best predictor of what persons can and will do in present and future situations is what they have actually done in similar past situations.

\section{Research Methodology}

\subsection{Research Design}

Descriptive research design has been used in the study as it is an observational study.

\subsection{Sample Size}

The sample size is 75 . A total of 100 questionnaires were distributed among the employees, out of which only 75 filled questionnaires were received. In the survey, nonrandom sampling has been used.

\subsection{Research Methodology}

- An extensive study of the topic through various sources and data available in books, journals and internet, magazines and handbook of Delhi Metro.

- A questionnaire was formulated so that to know the views and responses of the employees and analyze them.

\section{Data Analysis \& Intrepretation}

\subsection{Competency Survey for Senior Supervisor, Assistant Managers \& Managers of Dmrc}


Q.1) According to you what are the employees competencies required for these different functions in an organization?

Table 1. Descriptive Statistics for the employees competencies

\begin{tabular}{|c|c|c|c|c|c|}
\hline & $\mathrm{N}$ & Minimum & Maximum & Mean & Std. Deviation \\
\hline employee_competencies_nonExecutive & 75 & 1.00 & 9.00 & 2.1467 & .99585 \\
\hline employee_competencies_supervisory & 75 & 1.00 & 8.00 & 2.1333 & 1.37873 \\
\hline employee_competencies_AssT_Manager & 75 & 1.00 & 8.00 & 4.4533 & 2.08789 \\
\hline employee_competencies_ManagerExecutive & 75 & 1.00 & 7.00 & 4.2133 & 1.75756 \\
\hline Valid N (list wise) & 75 & & & & \\
\hline
\end{tabular}

\section{Interpretations}

Measures of central tendency were computed to summarize the data for the employee competency required for different designations. Measures of dispersion were computed to understand the variability of scores for the employee competency for different designations". The ' $N$ ' stands for number of participants, the ' $M$ ' stand for mean and the 'SD' stands for standard deviation.

"The following are the results of the analysis;

1. NON EXECUTIVE: $\mathbf{N}=75, \mathbf{M}=2.1467, \mathbf{S D}=.995$

2. SUPERVISOR: $\mathbf{N}=75, \mathbf{M}=2.1333, \mathbf{S D}=1.37$

3. ASSIST MANAGER: $\mathbf{N}=75, \mathbf{M}=4.4533, \mathbf{S D}=2.08$

4. MANAGER: $\mathbf{N}=75, \mathbf{M}=4.2133, \mathbf{S D}=1.75$

After looking at the mean \& standard deviation for the different designations it appears that:

NON-EXECUTIVE: When we look at the mean, it appears that all the respondents have said that interpersonal group \& managerial effectiveness group is required for this level. However, if we look at the standard deviation, it is also agreeing with the fact stated above as the data is clustered i.e. going in the same direction.

SUPERVISOR: When we look at the mean, it appears that the requirement of competency is either leadership group or managerial effectiveness group.

However, based on the standard deviation, it looks like the competency required for this level varies.

ASSISTANT MANAGER: When we look at the mean it appears that highly required competencies are problem solving group \& intellectual competency for this post. It shows that the data is very scattered. However, based on the large standard deviation, it looks like the competency required varied quite a bit.

MANAGER: When we look at the mean, it appears that managerial effectiveness group \& problem solving group is highly required. However, based on the large standard deviation, it looks like competency required at this level varied quite a bit.

Q.2) According to you is there competencies gap present in these different functions in your organization?

\section{Correlations}

Table 2. Correlation of PC, MC, RC \& IC at Non-Executive level

\begin{tabular}{|c|c|c|c|c|c|}
\hline & & $\begin{array}{l}\text { compgap_non } \\
\text { executive_PC }\end{array}$ & $\begin{array}{c}\text { compgap_non } \\
\text { EXECUTIVE_MC }\end{array}$ & $\begin{array}{c}\text { compgap_non } \\
\text { EXECUTIVE_RC }\end{array}$ & $\begin{array}{c}\text { compgap_non } \\
\text { EXECUTIVE_IC }\end{array}$ \\
\hline \multirow{3}{*}{$\begin{array}{l}\text { Compgap non } \\
\text { executive_PC }\end{array}$} & $\begin{array}{c}\text { Pearson } \\
\text { Correlation } \\
\end{array}$ & 1 & $-.245^{*}$ & $-.713 * *$ & $-.391^{* *}$ \\
\hline & Sig. (2-tailed) & & .034 & .000 & .001 \\
\hline & $\mathrm{N}$ & 75 & 75 & 75 & 75 \\
\hline \multirow{3}{*}{$\begin{array}{c}\text { Compgap non } \\
\text { EXECUTIVE_MC }\end{array}$} & $\begin{array}{c}\text { Pearson } \\
\text { Correlation } \\
\end{array}$ & $-.245^{*}$ & 1 & -.156 & $-.257^{*}$ \\
\hline & Sig. (2-tailed) & .034 & & .182 & .026 \\
\hline & $\mathrm{N}$ & 75 & 75 & 75 & 75 \\
\hline \multirow{3}{*}{$\begin{array}{c}\text { compgap_non } \\
\text { EXECUTIVE_RC }\end{array}$} & $\begin{array}{c}\text { Pearson } \\
\text { Correlation } \\
\end{array}$ & $-.713^{* *}$ & -.156 & 1 & $.545^{* *}$ \\
\hline & Sig. (2-tailed) & .000 & .182 & & .000 \\
\hline & $\mathrm{N}$ & 75 & 75 & 75 & 75 \\
\hline \multirow{3}{*}{$\begin{array}{c}\text { compgap_non } \\
\text { EXECUTIVE_IC }\end{array}$} & $\begin{array}{c}\text { Pearson } \\
\text { Correlation } \\
\end{array}$ & $-.391^{* *}$ & $-.257^{*}$ & $.545^{* *}$ & 1 \\
\hline & Sig. (2-tailed) & .001 & .026 & .000 & \\
\hline & $\mathrm{N}$ & 75 & 75 & 75 & 75 \\
\hline & & *. Correlation is & nt at the 0.05 level & & \\
\hline
\end{tabular}

\section{Interpretations}

\section{Non-Executive Level}

It can be said that PC is negatively correlated with all the other competencies i.e. MC, RC, IC it shows that if the gap for PC increases then for the other competencies it will decrease. So is the case for MC, it is also negatively highly correlated with all the other competencies and it is also sharing inverse relationship. But if we compare the relationship or RC with that of other competencies it is negatively correlated with PC \& MC i.e. inverse relationship but it is not at all related with IC because the correlation is not at all coming inside level of significance. Now lastly IC is also negatively correlated with PC \& MC i.e. inverse relationship but it is not at all related with RC because the correlation is not at all coming inside level of significance.

\section{Correlations}


Table 3. Correlation of PC, MC, RC \& IC at the Supervisory level

\begin{tabular}{|c|c|c|c|c|c|}
\hline & & $\begin{array}{c}\text { Compgap } \\
\text { Supervisory_PC }\end{array}$ & $\begin{array}{c}\text { Compgap } \\
\text { Supervisory_MC }\end{array}$ & $\begin{array}{c}\text { Compgap } \\
\text { Supervisory_RC }\end{array}$ & $\begin{array}{c}\text { Compgap } \\
\text { Supervisory IC } \\
\end{array}$ \\
\hline \multirow{3}{*}{ compgap_Supervisory_PC } & $\begin{array}{l}\text { Pearson } \\
\text { Correlation }\end{array}$ & 1 & $.332 * *$ & $.250 *$ & .038 \\
\hline & Sig. (2-tailed) & & .004 & .031 & .747 \\
\hline & $\mathrm{N}$ & 75 & 75 & 75 & 75 \\
\hline \multirow{3}{*}{ compgap_Supervisory_MC } & $\begin{array}{c}\text { Pearson } \\
\text { Correlation }\end{array}$ & $.332 * *$ & 1 & $-.337 * *$ & $.237 *$ \\
\hline & Sig. (2-tailed) & .004 & & .003 & .041 \\
\hline & $\mathrm{N}$ & 75 & 75 & 75 & 75 \\
\hline \multirow{3}{*}{ compgap_Supervisory_RC } & $\begin{array}{c}\text { Pearson } \\
\text { Correlation } \\
\end{array}$ & $.250^{*}$ & $-.337 * *$ & 1 & .095 \\
\hline & Sig. (2-tailed) & .031 & .003 & & .419 \\
\hline & $\mathrm{N}$ & 75 & 75 & 75 & 75 \\
\hline \multirow{3}{*}{ compgap_Supervisory_IC } & $\begin{array}{l}\text { Pearson } \\
\text { Correlation }\end{array}$ & .038 & $.237 *$ & .095 & 1 \\
\hline & Sig. (2-tailed) & .747 & .041 & .419 & \\
\hline & $\mathrm{N}$ & 75 & 75 & 75 & 75 \\
\hline
\end{tabular}

\section{Interpretations}

Supervisory Level - If we talk about MC it is not at all related with PC \& IC but it is related with RC and that too negatively i.e. if gap for one will increase, for other it will decrease. Now if we talk about RC, it is not at all related with PC \& IC but it is related with MC and that too negatively i.e. if gap for one will increase, for other it will decrease.

\section{Correlations}

Table 4. Correlation of PC, MC, RC \& IC at the Managers level

\begin{tabular}{|c|c|c|c|c|c|}
\hline & & & & & \\
\hline & & $\begin{array}{c}\text { compgap_Manager_execut } \\
\text { ive_PC }\end{array}$ & $\begin{array}{c}\text { compgap_Manager_executi } \\
\text { ve_MC }\end{array}$ & $\begin{array}{c}\text { compgap_Manager_executi } \\
\text { ve_RC }\end{array}$ & $\begin{array}{c}\text { compgap_Manager_execut } \\
\text { ive_IC }\end{array}$ \\
\hline \multirow{3}{*}{$\begin{array}{l}\text { compgap_Man } \\
\text { ager } \\
\text { executive_PC }\end{array}$} & $\begin{array}{l}\text { Pearson } \\
\text { Correlati } \\
\text { on }\end{array}$ & 1 & $.578^{* *}$ & $-.336 * *$ & -.066 \\
\hline & $\begin{array}{l}\text { Sig. (2- } \\
\text { tailed) }\end{array}$ & & .000 & .003 & .574 \\
\hline & $\mathrm{N}$ & 75 & 75 & 75 & 75 \\
\hline \multirow{3}{*}{$\begin{array}{l}\text { compgap_Man } \\
\text { ager } \\
\text { executive_MC }\end{array}$} & $\begin{array}{c}\text { Pearson } \\
\text { Correlati } \\
\text { on } \\
\end{array}$ & $.578^{* *}$ & 1 & -.199 & $.349 * *$ \\
\hline & $\begin{array}{l}\text { Sig. (2- } \\
\text { tailed) }\end{array}$ & .000 & & .086 & .002 \\
\hline & $\mathrm{N}$ & 75 & 75 & 75 & 75 \\
\hline \multirow{3}{*}{$\begin{array}{l}\text { compgap_Man } \\
\text { ager } \\
\text { executive_RC }\end{array}$} & $\begin{array}{l}\text { Pearson } \\
\text { Correlati } \\
\text { on }\end{array}$ & $-.336 * *$ & -.199 & 1 & $-.239 *$ \\
\hline & $\begin{array}{l}\text { Sig. (2- } \\
\text { tailed) }\end{array}$ & .003 & .086 & & .039 \\
\hline & $\mathrm{N}$ & 75 & 75 & 75 & 75 \\
\hline \multirow{3}{*}{$\begin{array}{c}\text { compgap_Man } \\
\text { ager } \\
\text { executive_IC }\end{array}$} & $\begin{array}{c}\text { Pearson } \\
\text { Correlati } \\
\text { on } \\
\end{array}$ & -.066 & $.349 * *$ & $-.239 *$ & 1 \\
\hline & $\begin{array}{l}\text { Sig. (2- } \\
\text { tailed) }\end{array}$ & .574 & .002 & .039 & \\
\hline & $\mathrm{N}$ & 75 & 75 & 75 & 75 \\
\hline \multicolumn{6}{|c|}{ **. Correlation is significant at the 0.01 level (2-tailed). } \\
\hline \multicolumn{6}{|c|}{ *. Correlation is significant at the 0.05 level (2-tailed). } \\
\hline
\end{tabular}




\section{Interpretations}

\section{Manager}

It can be said that PC is negatively correlated with all the other competencies i.e. RC, and not at all related with any other. Same is the case with the MC it is also negatively related with RC. If we compare the relation of IC with PC, RC\&MC it can be concluded that it is negatively correlated with PC\&RC and not at all related with MC.

\section{Findings}

- The company has an effective and time tested system of competency mapping which is working satisfactorily.

- The employees are satisfied with the current competency mapping procedure. The present method of competency mapping is providing the company with effective and efficient manpower, which is getting reflected in the performance of the company and its market image and reputation which has improved significantly over the years.

- Existing employees are well informed about the competencies needed to perform excellent work in an organization.

- Growth and expansion of Delhi Metro is the major factor that affects the competency mapping in organization as they need more and more people to achieve their mission i.e. to cover whole of Delhi by metro network by the year 2021 .

\section{Conclusions}

After analyzing the different parameters of mapping, assessing, filling the gap of the competency of an employee, it can be concluded that it is not dependent on an individual's parameters. Each employee may have a different competency level. Some may be fulfilling the competency level according to their job positions or some may not. Some employees will feel that there is no need to give them training and development but some may feel that it is required on a very urgent basis to fill their competency gap.

So broadly we can divide the need of competency mapping on two factors:

- Identify the competency gap: Different techniques should be adopted such as interviews, work sample tests, on the job performance, annual confidential report, 360 appraisal \& peer appraisal. The study found that most often used tools are on the job performance \& annual confidential report because they provide maximum transparency \& accuracy in the results. Hence it is very necessary to find out the gaps so as to eliminate the hindrances and employee can work effectively and efficiently.

- Proper training and development: the training and development not only helps an employee to reach at predetermined competency level but also helps the organization in optimum utilization of resources, provides an opportunity for the development of human resources and development of skills of an employee i.e. behavioral and technical skills. Hence it is beneficial for employees as well as organization. Different training and development programs such as on the job training lectures, programmed instructions, simulations, and computer aided instructions, business games, orientation programs \& seminars can be very useful in this regard.

\section{References}

[1] Anderson, K. (2007) "Education and training for records professionals”, Records Management Journal, Vol. 17, No. 2, pp. 94-106.

[2] Bawden, D., Vilar, P., Zabukovec, V. (2005) "Education and training for digital librarians. A Slovenia/UK comparison”, Aslib Proceedings: New Information Perspectives, Vol. 57, No. 1, pp. 85-98.

[3] Gary Desslar Human Resource Management, 7th Edition. 1997 Prentice Hall, New Jersey Page-353-365 ISBN-81-203-1230-5.

[4] Indira Gandhi National Open University School Of Management Studies Organizational Development And Change Ms-10 Page-8698.

[5] Leong, J. (2008) "Academic reference librarians prepare for change: an Australian case study”, Library Management, Vol. 29, No. $1 / 2$, pp. $77-86$

[6] Platts, K., Tan, K.H. (2004) "Strategy visualisation: knowing, understanding, and formulating", Management Decision, Vol. 42, No. 5, pp. 667-676

[7] Rothwell, W., \& Wellins, R. (2004). Mapping your future: Putting new competencies to work for you. Training and Development, 58 (5), 94-102

[8] Sandberg, J. (2000). Understanding human competence at work: An interpretative approach. The Academy of Management Journal, 43 (1), 9-25.

[9] Sandwith, P. (1993). A hierarchy of management training requirements: The competency domain model. Public Personnel Management, 22, 43-63.

[10] Shippman, J. S., Ash, R. A., Battista, M., Carr, L., Eyde, L. D., Hesketh, B., Kehoe, J. Pearlman, K., \& Sanchez, J. I. (2000). The practice of competency modeling. Personnel Psychology, 53, 703740.

[11] Schöpfel, J. (2003) "INIST-CNRS in France: 'a model of efficiency’”, Interlending \& Document Supply, Vol. 31, No. 2, pp. 94-103.

[12] Tammaro, A.M. (2005) "Recognition and quality assurance in LIS New approaches for lifelong learning in Europe”, Performance Measurements and Metrics, Vol. 6, No. 2, pp. 67-79.

[13] Tikkanen, H., Pölönen, P. (1996) "Business process reengineering projects on Finland. An evaluation of change management in 21 large Finnish organizations”, Business Process Re-engineering \& Management Journal, Vol. 2, No. 3, pp. 10-25.

[14] Van der Klink, M., \& Boon, J. (2002). The investigation of competencies within professional domains. Human Resource Development International, 5 (4), 411-424.

[15] Youn Chyung, S., Stepich, D., \& Cox, D. (2006). Building a competency-based curriculum architecture to educate 21st-century business practitioners. Journal of Education for Business, 81 (6), 307-314.

[16] Zingheim, P. K., Ledford, G. L., \& Schuster, J. R. (1996). Competencies and competency models: Does one size fit all? ACA Journal, 5 (1), 56-65.

[17] Zingheim, P.K., and J.R. Schuster (1995). "Moving One Notch North: Executing the Transition to New Pay." Compensation \& Benefits Review. pp. 33-39. 